\begin{tabular}{|c|c|}
\hline \multicolumn{2}{|r|}{ About the Journal } \\
\hline Journal DOI & https://doi.org/10.21659/rupkatha \\
\hline Journal Home & www.rupkatha.com \\
\hline Indexed by & Scopus $₫$ Web of Science: Emerging Sources Citation Index (ESCI) DOAJ \\
\hline Journal Metrics & CiteScore 2020: 0.2 | SJR 2020: 0.162 | SNIP 2020: 0.193 | JCI 2020: 0.50 \\
\hline \multicolumn{2}{|r|}{ About the Issue } \\
\hline Themed issue & $\begin{array}{l}\text { Volume 4, number 1, } 2022 \text { (January-March) | Contemporary East and } \\
\text { Southeast Asian Literary and Cultural Studies }\end{array}$ \\
\hline Guest Editors & Dr Jeremy de Chavez $\oslash$ \& Dr Zhang Yue, University of Macau, China \\
\hline Issue DOI & https://doi.org/10.21659/rupkatha.v14n1 \\
\hline TOC & https://rupkatha.com/v14n1.php \\
\hline Peer Review & Under the responsibility of the Guest Editors \\
\hline \multicolumn{2}{|r|}{ About the Article } \\
\hline Title & Traversing Paths/Pasts: Places of Filipino Philosophy \\
\hline Author/s & Hazel T. Biana $\otimes$ \\
\hline Affiliation & Department of Philosophy, De La Salle University, Manila, Philippines \\
\hline Author ID & https://orcid.org/0000-0002-7837-8893 \\
\hline Funding & $\begin{array}{l}\text { De La Salle University's University Research Coordination Office (DLSU- } \\
\text { URCO) (No. } 33 \text { F U 2TAY19-3TAY20). }\end{array}$ \\
\hline Article DOI & https://doi.org/10.21659/rupkatha.v14n1.08 Pages: 1-13 \\
\hline Abstract & https://rupkatha.com/v14n108 \\
\hline Full-text PDF & https://rupkatha.com/V14/n1/v14n108.pdf $\square$ \\
\hline \multirow[t]{3}{*}{ Article History } & Abstract received: 19 Feb 2021 | Complete article received: 3 June 2021 \\
\hline & Revised article received: 25 Aug 2021 | Accepted: 29 August 2021 \\
\hline & First Published: 05 February 2022 \\
\hline Article Impact & Check Dynamic Impact $\oslash$ \\
\hline Copyright & Author \\
\hline Licensing & Creative Commons Attribution Non-Commercial 4.0 \\
\hline
\end{tabular}

This Open Access article is published under a Creative Commons Attribution Non-Commercial 4.0 International License (http://creativecommons.org/licenses/by-nc/4.0/), which permits non-commercial re-use, distribution, and reproduction in any medium, provided the original work is properly cited. For citation use the DOI. For commercial re-use, please contact editor@rupkatha.com. 
1 Rupkatha Journal, Vol. 14, No. 1, 2022

Research Article

\title{
Traversing Paths/Pasts: Places of Filipino Philosophy
}

\author{
Hazel T. Biana \\ Department of Philosophy, De La Salle University, Manila, Philippines
}

\begin{abstract}
Place is a vital framework of human experience and is essential to the configuration of experience. It is more than the mere geography or arrangement of things in a particular spatial location. As a concept and not merely as a specific instance, place moulds human experience and contributes to the understanding of oneself and the world. Philosophers have long tackled the unravelling of these significant experiences, and the importance of theorizing about the place. As such, understanding philosophy also necessitates looking into its place. Regrettably, Filipino Philosophy has not yet been examined closely in this regard. To address this gap, this paper inquires about the development of Filipino Philosophy as it has been shaped by the places of its pioneers. It uncovers the connections between the development of Filipino thought and the places of Filipino philosophers who emerged in the 1970s-80s. By culling these philosophers' paths/pasts, homage is paid to a significant resource often ignored, viz., the places of philosophy.
\end{abstract}

Keywords: Philosophy of Place, Filipino Philosophy, Travel, Philippines

"A place belongs forever to whoever claims it hardest, remembers it most obsessively, wrenches it from itself, shapes it, renders it, loves it so radically..."

Joan Didion, American Writer

\section{Introduction}

The history of Western philosophy can be traced to Ancient Greece. Famous philosophers from that era, such as Thales of Miletus, Pythagoras of Samos, Heraclitus of Ephesus, and so on, are always referred to in relation to their birthplaces. Greek philosophers are always referred to in connection to their places. Nowadays, however, although always hailing from and moving to and from particular places, philosophers and their philosophies seem to have been disassociated from their places. Edward Casey (2013) claims that since the place has always been there, it has been marginalized by the topics of space and time. Despite millennia of "place-talk" (from Aristotle to Luce Irigaray), placement has been hidden and unacknowledged in relation to philosophers. This dislocation from place has also been attributed by Casey to global conflicts, forced migrations, displacement and technological advancements.

Place is more than mere geography or the arrangement of things in a particular spatial location, it is a vital framework of human experience, and is essential to the configuration of experience (Malpas, 2018, p. ix). Humans, with their locomotive ability, always travel from place to place with the hope of going somewhere in life. With this concept and not merely as a specific instance, place moulds human experience and contributes to the understanding of oneself and the world. Place also accords the understanding of philosophy. From Immanuel Kant to Henri 
Bergson, the importance of place in philosophy has already been discussed (Malpas, 2018). More recently, other philosophers such as Martin Heidegger, Jacques Derrida, Gilles Deleuze, and Félix Guattari have also reemphasized the formative influence of place (Malpas 2018). In Philosophy, travel, and place (2018), Ron Scapp and Brian Seitz claim that place and travel is one of the neglected and devalued themes in the field of philosophy and culture. Philosopher of place, Jeff Malpas (2018), states that the world reveals itself through place, and this world is not just personal, but the bigger historical, cultural, environmental, and natural worlds. This must include the philosophical world as well.

Place and travel have their place in philosophy, and it affects and influences philosophy. Where one is placed, influences values, beliefs, behaviours, experiences and expectations. They can be limited or privileged by their places of origin, present locations, or places that they travel to or places that they travel from. Philosophy cannot be separated from the philosopher's place as human beings are always located and situated at particular places. Some philosophers have written their thoughts in secluded places. Gottfried Leibniz, Immanuel Kant, and Søren Kierkegaard came up with their thoughts on their chairs and desks in the comforts of their homes (Craig \& Casey, 2018). Others, though, while travelling certain paths. Plato, Martin Heidegger, Martha Nussbaum, philosophized while traversing Stoa, Heidelberg, and Chicago respectively (Craig \& Casey, 2018). Other philosophers have done both as they would work in private and would get lost in their thoughts while writing in transit.

Filipino philosophers, in a similar way, have had their share of travels and experiences of place as well. For example, Emerita Quito, who studied in and extensively travelled Europe, and Rolando Gripaldo, who has likewise attended fellowships and conferences in four continents, have supposedly been influenced by the places they have been to. With scarce literature on this topic, it is an intriguing and novel task to uncover the role of place in their philosophies. Since these well-known Filipino philosophers have travelled all over the country and the world, this paper takes a theoretical trip down the memory lane and traverses through their thoughts by revisiting the places they have travelled to. This paper retraces the paths, pasts, and places of four prolific philosophers from De La Salle University, Manila: Romualdo Abulad, Claro Ceniza, Rolando Gripaldo, and Emerita Quito.

Divided into parts, this paper looks at the philosophy of place as a framework, the pioneers of Filipino philosophy, the tracing of Filipino philosophers' lives and works by looking at their biographies with particular emphasis on place, and the extraction of themes from works they have come up with given the places in their lives. Malpas (2018) refers to this process as descriptive mapping. wherein a "situating" of the philosophers' works will be done within place. By transiting through their works and biographies, this paper looks at how places have influenced and shaped the ideas of Filipino philosophers. It also looks at Filipino philosophers' thoughts and ways of thinking, through their places through a "careful descriptive mapping" of "placedness", and a "scenography of placement itself" (Malpas, 2018, p. ix). Culling paths/ pasts as data, this study pays homage to a significant resource often ignored, the places of philosophy.

\section{The Philosophy of Place}


Philosophers' thoughts are always influenced by their context, and in this case, their place. A philosopher's place includes the following aspects: current location, place of origin and/or place of birth (not necessarily the same places), place of migration, one's culture and background influenced by one's place (region, city, municipality, continent, country etc.), place of citizenship, language/s, and the place of ancestors and descendants, or even the food of a particular place (Biana \& Nalam, 2020)! Travelling from place to place disrupts habit and opens the possibility for knowledge (Rawlinson, 2018). In Thinking in transit, Megan Craig and Edward Casey (2018) talk about their experiences as travelling philosophers or philosophers in transit, and how fresh energies and novel trajectories of thought have encouraged writing and creative work. As an example, Friedrich Nietzsche metamorphosed in his writings as he travelled to Germany, Switzerland, France and Italy (Krell, 2018). Mary Wollstonecraft (1894), on the other hand, wrote personal narratives through letters during her short residence in Sweden, Norway, and Denmark.

Nietzsche made breakthroughs in his thoughts and writing when he travelled to various European countries. When he was in Switzerland, Nietzsche pronounced that near the Chärstelenbach river, "[I]t is the right moment and the right place to see things as yet unseen. . . (where) It is an utterly enchanted world: nature celebrates her feast of reconciliation with humanity" (Nietzsche as cited in Krell 2018, p. 176). Furthermore, Nietzsche mentioned that the "sharpest degree of understanding" that he has ever found was when he was in Venice, Italy, and that everything he has written before such a place is "foreground" (Nietzsche as cited in Krell 2018, p. 182). Moreover, Nietzsche also invited "researchers" to surround themselves with "the treacherous sea or the merciless mountain heights", as insight should not be inspired without danger (Nietzsche as cited in Krell 2018, p. 184).

In Wollstonecraft's (1894, p. 105) trip to Strömstad, Sweden, she claims that her journey has given her "fresh force" to her opinion and strengthened her mind through "solitary musing". Furthermore, while wandering alone with such a clear atmosphere and desirable solitude, Strömstad stored her mind with ideas "with astonishing rapidity" (1894, p. 104). In Wollstonecraft's (1894, p. 192) last letter, which concludes the narration of her trip to Scandinavia, she declared that her northern journey confirmed her view that society's "change is gaining ground with (such an) accelerating pace" and change in government policies and laws may only be "useful and permanent" if particular nations' understandings are "matured by time". Such is the connection between travel and transformation, and how travel may broaden the mind. In terms of places and journeys, there are some which have vital potential for transformation (Morgan, 2010). Philosophers are transformed by new environments and they gain understanding and deeper insights from experiences with such places (Keyserling, 1925). Emily Thomas (2020) affirms that philosophy should ask more questions about travel, such as how philosophy has changed travel, and how one can ponder more deeply about journeys. She mentions George Berkeley as an example of a philosopher who led a life beyond the armchair, and "fought off wolves in a French mountain pass" (Thomas, 2020, p. 3).

Both travel and the stability of place contribute to the thinking life (Craig \& Casey, 2018). Count Hermann Keyserling (1925, p. 9), in The travel diary of a philosopher, recognized the "external stimulus of a journey around the world" and the "many moods and transformations" of wanderers. Hailing from Europe, he criticized the place as too familiar that it had nothing more to 
give him. Keyserling (1925, p. 17) craved travel to new places, as different surroundings would "make existence possible", and would effect "a radical renewal of one's means of comprehension". As such, he situated his philosophy in his places of travel and his places of travel in his philosophy. For Michael Peters (2010, pp. 454), exile is an educational experience which is based on "finding oneself in another or shoring up one's identity in other cultural terms," and exilic thought is a type of philosophical discourse "that recognizes the spatial dimension of thought and its necessary complement when one travels and settles," while bringing new-fashioned perspectives. George Santayana, the author of The philosophy of travel (1964), illustrated his philosophical travels through his physical travels, and moral geographies through physical geographies (Fantini, 2011).

Feminist theorist and cultural critic bell hooks (2009) charted her journeys in the past and present and examined issues about place and belonging, and concluded that everyone yearns to find their place in the world. Hooks $(2009$, p. 5) used her past as "raw material", compelling her to think critically about her native place. On a similar note, Malpas' (2018) took off from Marcel Proust and Maurice Merleau-Ponty, and came up with a framework of place that acknowledges the notion of subjectivity as founded on place. Proust explicates the relationship of persons and places, of how life is always in a location, and that identity is established in place. Meanwhile, MerleauPonty, talks about how inner life is also found in outer places. In consequence, "to be a human subject at all - to think, feel, and experience - is to be emplaced" (Malpas, 2018, p. ix). When people are "placed" or in place, this phenomenon is referred to by Casey $(1993$, p. 179) as entering the "cultivational place-world". This is where one can imagine, remember, both the self and the other, primary and secondary qualities; and there are many place-worlds in one's lifetime (i.e., home, places of travel, etc.). Place escorts identity, character, nuance, and history. Furthermore, experience is multiplied in place, as spatiality is both lived time multiplied by the person's lived space (Malpas, 2018, pp. ix-x). These places are particular though (like localities), and they constitute self-conception and self-identity. Understanding the particular places where one is situated helps persons grasp objects, others, and of course, themselves (Malpas, 2018, p. 180).

\section{The Places of Filipino Philosophy Pioneers ${ }^{i}$}

Emplaced as they are, individual Filipino thinkers have long grappled with philosophical issues through their thoughts and works (Gripaldo, 2013). As in British philosophy, German philosophy, French philosophy, or American philosophy, there exist individual British, German, French, or American thinkers who have contributed to bodies of philosophical literature. This approach is based on the Greek model of philosophy, wherein "genuine or an authentic Filipino philosophy" can be gathered from the "body of philosophical literature that is produced by Filipino individual thinkers" (Gripaldo 2014, p. 2). Early Filipino philosophers were Enlightenment thinkers who travelled to Spain from France, and eventually back to the Philippines, and their exposure to European thinkers influenced their brand of philosophizing (Gripaldo, 2014). Nicolito Gianan (2012) likewise attributed the colonized acquisition of (Western) knowledge to their travels to the Metropolis and other countries. Some of these thinkers were Emilio Aguinaldo, Marcelo H. del Pilar, Graciano Lopez Jaena, Apolinario Mabini, and of course, Philippine national hero Jose Rizal. 
The recent pioneers of Filipino philosophy, however, have emerged during the 1970s1980s. These philosophers include Abulad, Ceniza, Gripaldo, and Quito. Their contributions to Filipino thinking are varied and worth acknowledging for they not only produced numerous articles and books but also represented the country in the international arena. To argue for the prospect of the influence of place, the following configurations of place are looked at in relation to the selected Filipino philosophers' thoughts and works: their birthplaces, places of origins, places of migration and travel, language/s, and others. To strengthen their being emplaced, the places they travelled to were highlighted.

\section{Romualdo Abulad (1947-2019)}

Romualdo Abulad was born in Lucban, Quezon, Philippines. He went through his primary and secondary education in Lucban as well. He attributes his fluency in English and Tagalog to his teachers in general education (De Leon, 2016). Abulad worked in Cebu City, Central Province, Quezon City, and Manila. He pursued studies in philosophy and theology in Manila and Tagaytay City where he worked on Kantian ethics, Kantian epistemology, Kantian and Shangkaracharyan psychologies, Kant and scientific metaphysics, and Christology. While in the University of Santo Tomas (UST), Abulad claims to have strengthened his background in Thomistic philosophy but eventually got tired of the Scholastic themes (De Leon, 2016). He later travelled to Germany to work on his postdoctoral studies at the University of Hamburg and the University of Freiburg. Abulad left the Philippines and went to Germany to deepen his Kantian studies, and to further master the German language to be able to read Kant in its original German form. In the Philippines, Abulad worked on Filipino philosophy, postmodernism and continental philosophy themes, while continuing his Kantian-themed works.

\section{Claro Ceniza (1927-2001)}

Claro Ceniza was born in Cebu City, Philippines. Being the child of a judge, he always had to move around districts. Ceniza spoke various languages, and these include Cebuano, English, French, Spanish, Tagalog, and a little bit of Chabacano. He lived in Oroquieta for a time (the capital of Misamis Occidental, an hour away from Ozamiz City), and in Dumaguete and Zamboanga as well. According to Feorillo Demeterio (2014, p. 186), "(Ceniza) practised the profession for twelve years before totally giving it up for the academic life of a philosopher teacher". His interest in philosophy was piqued by reading Rene Descartes' Discourse on method during World War II. Known for metaphysics, his ideas for such followed later on. Ceniza obtained his MA and PhD degrees from Syracuse University in Syracuse, New York. His thesis and dissertation were entitled "The Argument Of Parmenides" and "Some Basic Presuppositions Of Classical Philosophy" respectively. He also has an LL. B. degree from Silliman University in Dumaguete City. He taught philosophy in various universities in Manila, and Quezon City. Ceniza also went to Hong Kong to attend a two-week workshop on higher education and Knoxville, Tennessee for a conference on environmental education. He was also a visiting professor at Drury College, Springfield, Missouri, and Waseda University, Tokyo, Japan. He would visit Baguio City and Legazpi City for various lectures. His books 
6 | Traversing Paths/Pasts: Places of Filipino Philosophy

and papers had themes on metaphysics, logic, philosophy of law, philosophy of science, philosophy of language, symbolic logic, epistemology, ethics, and political philosophy.

\section{Rolando Gripaldo (1947-2017)}

Rolando Gripaldo was born in Cantilan, known as the "Cradle of Towns" in Surigao del Sur, Philippines. Languages spoken in the province include Surigaonon, Agusan, Cebuano, and Tagalog. Exposed to various Filipino languages, this is probably the reason why Gripaldo delved into the discussion of The north and south of a national language (1985). He first became fascinated with the philosophical foundations of logic in college at the Mindanao State University (MSU) as an engineering student. When he moved out of the province, he pursued his Master of Arts in Philosophy degree in the University of the Philippines-Diliman (UPD), Quezon City, where he wrote about the concept of freedom of choice and worked on the philosophy of language themes. It should be noted that UPD is known for its strength in analytic philosophy during this time. He worked on Filipino philosophy in UPD for his PhD research as well. When he worked as a professor in the MSU in Marawi, Gripaldo examined Western philosophy, Chinese and Japanese philosophy (Oriental philosophy) themes. Gripaldo (2004) then realized that he was studying something that he could not relate to, thus, the need for a philosophy that is grounded on the Filipino historical experience. Eventually, he started writing about Filipino philosophical approaches, the history of philosophy in the Filipino context, and issues plaguing it. As a visiting research professor in the Catholic University in America, Washington DC, Gripaldo also attended the Eastern Division Conference of the American Philosophical Association (APA). Probably one of the most well-travelled among Filipino philosophers, Gripaldo visited the following places in the course of reading papers: Cambodia (Phnom Penh and Siem Reap), Germany, Greece, Iran (Persepolis and Tehran), Japan (Narita and Nagoya), Indonesia, Korea (Bucheon and Seoul), Lebanon (Baalbek, Byblos, Cedars Mountain and Louaize), Malaysia (Kuala Lumpur and Penang), Nigeria (Ibadan and Lagos), Qatar, Singapore, Taiwan, Thailand, Turkey, United States (Delaware, Indianapolis, Maryland, Milwaukee, New Haven, New York, New Jersey, Vermont, Virginia, Washington DC), and Vietnam. Some of the themes of his papers are on the philosophy of language (on speech acts), and of course, Filipino philosophy.

Gripaldo $(2006,2009 a)$ produced a wide array of works discussing Filipino philosophy, the problems with pursuing philosophy as a discipline in the Philippines, the various approaches to the study of philosophy, and documentation of the thoughts of Filipino reformists and revolutionaries.

\section{Emerita Quito (1929-2017)}

Emerita Quito was born in San Fernando, Pampanga. As such, she spoke Kapampangan, but strove to write in polished Filipino (De Leon, 2016). She pursued studies in the city of Manila, and she wrote her Master of Arts thesis on "The Will and Its Relation to Divine Causality and Knowledge" in 1956. In the 1960s, when she pursued further studies in the Université de Fribourg, Switzerland, Quito immersed herself in the works of Henri Bergson, Albert Camus, Edmund Husserl, Karl Jaspers, Martin Heidegger, Gabriel Marcel, and Jean-Paul Sartre among others. This was also the time when 
she strengthened her work on Plato. In the 1970s, Quito was invited to pursue a grant at the University of Paris at the Sorbonne, Paris, France, where she worked on comparative philosophy, and Sanskrit. Quito would then write in the French language. She also travelled to other Asian countries such as Japan, Malaysia, Singapore, and Taiwan as a visiting scholar, and worked on papers on Occidental Philosophy, comparative philosophy, the philosophy of history, and the historicity of philosophy. She also travelled to Korea to present a paper on women's consciousness. In the 1980s, Quito travelled to Nancy and Paris, to teach at the University of Nancy II and the University of Paris II. In this stint, she started working on Filipino philosophy and education, while still continuing her work on European philosophy. Other places she travelled to include Hawaii, Portugal, and Thailand where she also worked on the philosophy of religion. While in Manila, Quito would also touch on the topics of women's studies, existentialism, structuralism and poststructuralism, deconstruction and hermeneutics. Quito retired and passed away in Baguio, a city 250 kilometers north of Manila, in a place with a view of the mountain ranges.

\section{Traversing Paths/ Pasts}

As these philosophers moved around, their places have influenced their thoughts and works. The development of Filipino philosophy was shaped and contextualized by the places of the pioneers. For instance, both Gripaldo and Quito have "discovered" their call to write about Filipino philosophy themes after working extensively on Western and other Eastern philosophy themes. Gripaldo discovered the lack of an inward-looking Filipino philosophy while working on other philosophies in Marawi. When Gripaldo was invited to present his paper entitled My Philosophical Development (2009b) as part of the conference theme of "Teaching Philosophy in the Asian Context' (2009a)' in Ateneo de Manila University, he narrated that the content of his philosophical studies during his undergraduate years at MSU up until his graduate studies at the UPD consisted primarily of Western and Oriental (Indian, Chinese, and Japanese) philosophies. At MSU, he "taught essentially Western philosophy with some occasional courses in Chinese and Japanese philosophy" and realized that everything he learned was "alien in origin and not contextually Filipino, that is to say, not a type of philosophy that is grounded on Filipino historical experience" (Gripaldo, 2004). He then decided to leave Marawi, pursue further Philippine studies in UPD to investigate more into this lack of inward-looking Filipino philosophy. Until recently, "evidence remains in the Philippines where contemporary philosophical thought continues to have a fundamental Western orientation" (Gianan, 2012, p. 198). Gripaldo was able to identify what the nature of Filipino philosophy is while still acknowledging the influence of Western and Eastern philosophies. It was also his move to Metro Manila that paved the way for the publication of several works on prominent Filipino thinkers such as Rizal, Bonifacio, and Jacinto among others (Gripaldo, 2009b).

Quito, on the other hand, worked on The state of philosophy in the Philippines (1983) after she returned from her studies abroad and was given an administrative post in the university. Of the four Filipino philosophers, Gripaldo and Quito seem to be the most travelled. While Quito pursued studies in Switzerland and France and visited various countries for invited lectures before her retirement, Gripaldo had been to four continents in the span of his seven-decade life to attend conferences and expound his philosophical network. His exposure to these places contributed to 
the recognition of the lack of a proper Filipino philosophy and philosophy education in the Philippines, and the need to spread the word about emerging Filipino philosophies.

What is common among Abulad, Gripaldo, and Quito though, is that they seriously went into discussing Filipino philosophy after being exposed to Western and Asian philosophies, visiting places abroad and learning from foreign teachers. Ceniza, on the other hand, worked on the importance of philosophy in (higher) education, and "Logic and Critical Thinking for Filipino Teachers" which could likely be an effect of his exposure to fellowships and conferences sponsored by the United Board for Christian Higher Education in Asia (UBCHEA) in the United States and Hong Kong. These instances could affirm Keyserling, Morgan, Craig and Casey's assertions that travelling to places broadens the mind. This is probably similar to Gripaldo's thesis on the influence of Europe on Filipino enlightenment philosophers, as Thomas (2020) insists as well that places affect philosophy.

Before delving into Filipino philosophy though, Quito and Abulad went to the places that nurtured the philosophers that they were studying. Since Abulad was seriously studying Kantian philosophy, he applied to the Alexander von Humboldt Foundation and eventually ended up in Hamburg (De Leon, 2016). Abulad specified in one of his interviews that if he no longer learned anything from a certain place, there was a need to move or leave a place (De Leon, 2016). In one instance, he said that "After a while, narealize kong wala na akong matutunan tungkol kay Kant sa UST. At iyon ang nag-move sa akin papuntang Ateneo" ("I realized I can no longer learn about Kant in UST, so that made me decide to move to Ateneo") (De Leon, 2016 p. 10). Abulad (De Leon, 2016 p. 6) also acknowledged that his well-travelled teachers were "parang fresh air" or like fresh air that rocked the stable system, as they were consistent sources of newer philosophies. When Abulad decided to go to Hamburg, he claimed "alam ko na ang kulang ko...So, alam ko na ang dapat kong gawin ay pumunta ng Germany" ("I knew my knowledge (on Kant) was lacking, I knew I needed to go to Germany") (De Leon, 2016 p. 11). This intention to re-place oneself to broaden one's intellectual horizons can be termed as placifying or simply to placify, which of course goes hand-in-hand with place-mindedness or the open-mindedness to re-place. Peters (2010, p. 446) refers to this kind of uprooting as the development of "exilic thought", or "the thought and 'education' of the exile":

"It is a kind of uprooted thought developed away from 'home' under conditions of displacement and uncertainty, often in a different mother tongue, language tradition and culture. Exilic thought is sometimes the self-imposed discipline of the 'stranger' who develops his or her identity as an 'alien' or immigrant against the conventions of a host culture and from the perspective of an outsider."

Similarly, Quito chose to placify or develop her exilic thought and went to Fribourg to immerse herself in the study of Plato and European philosophy, and Paris, France (the birthplace of Sartre, who was one of her profound influences). In these countries, she noticed that they used their language in teaching and writing philosophy. Quito then worked hard to write in Filipino (even if she primarily spoke Kapampangan), in her belief that one's language should be cultivated (de Leon, 2016). Furthermore, Quito also pointed out that the "dogmatic slumber" of philosophizing in the Philippines is due to restrictions put on philosophizing wherein only certain 
kinds of philosophies are taught or studied. As such, philosophy should be "open to different dimensions of wisdom" (de Leon, 2017 p. 37).

Quito left for Switzerland to strengthen her expertise, and upon her return, she shifted from the supposed dogmatic style of philosophizing and introduced new philosophies to Philippine education. De Leon (2017) described her work as a "paradigm shift" from the traditional textbook philosophizing to actual philosophizing which encourages independent thought. This same radical change in philosophizing was also acknowledged by Abulad when Quito became his teacher in UST (de Leon, 2016).

Although Ceniza did not go to Greece to study Parmenidean philosophy, he was awarded two Syracuse-in-Asia fellowships, and thus, he studied in New York. Most of Ceniza's "beginning" works on the subject of metaphysics, however, were written in the Philippines, in Oroquieta City, Mindanao and Dumaguete City. Ceniza believed that philosophy in the Philippines should commence in classrooms. He claims that students' perception of philosophy as "the most irrelevant of subjects" is due to the impersonal relation between the philosophical ideas and the Filipino experience (Ceniza 1982, 22). Gianan attributes the broadening of intellectual horizons in the country to travel to Western territories, but when Filipino thinkers returned to spread philosophical knowledge at home, there was a tendency to push aside "local and autochthonous forms of experience that were deemed less important" (Gianan, 2012, p. 198). Like Gripaldo, Ceniza (1982, p. 22) thereby asserted that teachers, while focusing on foreign ideas, do "often fail to relate them to specifically Filipino questions". Ceniza $(1982,24)$ also dreamt of a grander philosophical project where eventually individuals would "no longer think merely as Filipinos, as Frenchmen, Germans or Americans." and will "begin to think as men (persons)-as members of the great human race".

Abulad, Ceniza, Gripaldo and Quito are all learned in more than two languages (English and Filipino) due to exile, and their places of origin and travel. They have a grasp of non-English foreign languages due to the function of their upbringing (in the case of Ceniza), and pursuit of further studies. Abulad found it essential to comprehend German for his work on Kant, and Quito, French for her reading of the existentialists. These skills have proved to be vital for the understanding of primary, original texts in philosophy.

Nishida Kitarō states that one must view the world from the point of view of the world rather than the point of view of the self (Kitaro in Wen-Hong, 2009). This is probably the reason why Abulad got "sick and tired" of studying the same themes of scholasticism at UST and appreciated the broader world of philosophy brought by Quito (fresh from Europe) to the said institution (De Leon, 2016, p. 5). Similarly, Gripaldo attributed his grounding in aesthetics, history of philosophy, and Western philosophy to his American professors who visited MSU. This type of placifying, uprooting, or exile from a place, triggers novel ideas about places of origin, thereby instigating questions about national, cultural, and personal identities (Peters, 2010 p. 447). These places (of movement) are trademarks of twentieth-century thinkers, wherein estrangement enriches observations through different (or foreign/ alien) contexts (Peters, 2010 p. 447).

While place broadens perspectives though, it also tends to limit. For example, in Quito's (1983)

documentation of the status of philosophy in the country, she failed to go beyond the 
confines of Metro Manila-based universities (where she has taught for most of her life). Gripaldo (1988) criticized Quito for omitting information, for failing to mention MSU Marawi City in her brief historical survey of philosophy education. Gripaldo hailing from Mindanao, and Quito from Luzon, could be a function of the alleged conflict. After all, cultural identity is often interpreted as connected with a place, be it through "notions of local culture or calculated constructions of national identity" (Raadik-Cottrell, 2010, p. 33). Cultural identity is tied to the constructions of regional identity in the Philippines (Biana \& Nalam, 2020). Apart from being placist, some Filipinos are said to be more regionalist at that, wherein certain stereotypes and discriminations are reinforced by their beliefs and actions (Biana \& Nalam, 2020). In his review of Quito (1983) as well, Gripaldo (1988) stated that she was inaccurate and incomplete for neglecting certain achievements of the Southern regions.

It must be noted that the four philosophers all placified, or intentionally re-placed themselves thereby significantly contributing to the progress of their craft and Filipino philosophy (though they may have different definitions or ideas of it). Whether as teachers of philosophy in local universities, scholars or visiting researchers abroad, Filipino students of today are continuously being influenced by them and are still reading their works.

It is constructive to think about their places, too, to contextualize their trains of thought. Unfortunately, while their motivations cannot be verified anymore due to their passing, one can verify these from their auto/biographies and speculate about these philosophical place-worlds that nurtured their ideas. When Casey (1993) talks about entering a place-world, it is the exercise of imagining and remembering places that have cultivated an individual and their ideas. Through placiality, Stephen Hardy (2000) explains that detailed attention must be paid to the significance of place, and it is not merely about cultural nostalgia but rather exteriority, in Deleuze and Guattari terms. It is "going beyond and between the contours of a complex spatiality...exploring a new sense of placiality" (Hardy, 2000 p. 100).

In Belonging: a culture of place (2009), hooks invited native writers, poets, essayists, and cultural critics to look within their beloved native land to understand critical conversations about the development of their crafts. Gripaldo (2004, p. 2), likewise, recognized the belonging of individual philosophers according to their places of origin and consequently argued that a "Filipino philosophy similar to a Greek philosophy or a British/French/American philosophy can be had" only by looking inward rather than outward (into Western or Oriental philosophy). When one looks at the "relationships between space, place and human activity and perception," it indicates the "vital significance of a detailed attention to the significance of place" (Hardy, $2000 \mathrm{p}$. 100). For Malpas (2018) understanding these particular places contributes to self-conception and self-identity, which may eventually lead to a deeper grasp of objects and concepts, and in this case, even possibly, Filipino philosophy.

\section{Conclusion}

There is a connection between the development of Filipino thought and the places of Filipino philosophers who emerged in the 1970s-80s, as they have set the philosophical agenda for future Filipino philosophers. This is supported by a brief investigation of the journeys of various 
trailblazers of Filipino thought such as Abulad, Ceniza, Gripaldo and Quito. The comparison and contrasting of their places shows the trajectories of their type of philosophizing, and how places such as new environments have transformed their philosophies or even Filipino philosophy at that.

Abulad recognized the freshness of perspectives brought about by well-travelled Filipino philosophers to Philippine philosophical education and research. Furthermore, with this acknowledgement, Abulad placified himself to intentionally broaden his perspective on Kant. Ceniza, on the other hand, stressed the importance of grounding philosophy in the Philippine experience, and most of these musings on Filipino philosophy, he wrote in his homeland. Gripaldo (who was the most well-travelled), like Abulad, placified as well and moved to Metro Manila to learn more about Philippine studies. He travelled the world to spread Filipino philosophy from the point of view of Filipinos themselves. Of course, Quito began writing philosophy in Filipino, and pointed out the flaws in Philippine philosophical education, while revitalizing its very foundations. When Quito returned from Switzerland, she implemented revolutionary changes in the way philosophy was done in UST and other institutions, which were then cascaded and adopted by others as well during their time.

Place played a significant role in Abulad, Ceniza, Gripaldo and Quito's philosophical trajectories. Furthermore, their placedness contributed to the development of Filipino philosophy. While the philosophy of place as a framework is often neglected and taken for granted, the same can also be said about Filipino Philosophy and Filipino philosophers. The challenge, as such, is to ensure the continued traversing of various placial pasts and philosophical paths, to give justification to pioneering philosophers who have sought to put Filipino philosophy in its rightful place.

\section{Acknowledgements}

The author is grateful to those who have contributed directly or indirectly to the conception and completion of this paper: Fleur Altez-Albela, Babylyn Batlanggao, Nelly Ann Cruz, FPA Demeterio III, Rosallia Domingo, Adrienne John Galang, Jeremiah Joven B. Joaquin, Virgilio Rivas, Jonathan Rollins, Laura Snyder, Ben Oliver Tutor, her inexhaustible research assistant Francis Kenneth Raterta, and the anonymous reviewers for their constructive comments.

\section{Funding}

This author would like to thank De La Salle University's University Research Coordination Office (DLSU-URCO) for the faculty research grant provided for this project (no. 33 F U 2TAY19-3TAY20).

\section{Note}

' There is an ongoing debate as to whether Filipino Philosophy exists or not (Joaquin, 2010). Some have argued that Filipino Philosophy exists because there are works that could be identified through diverse categories and taxonomies (See Demeterio, 2014; Mabaquiao, 2012). Other scholars, on the other hand, have used cultural and anthropological approaches, and asserted that Filipino Philosophy may be based on 
indigenous worldviews and experiences through the analysis of language, literature, sayings, practices, and beliefs (See Mercado, 1976, 1994; Timbreza, 1999, 2017).

\section{References}

Biana, H. T., \& Nalam, R. M. (2020). Terms of Endearment: The Displacement of Inday. Asia-Pacific Social Science Review, 20(3), 102-110.

Casey, E. S. (1993). Getting Back Into Place: Toward a Renewed Understanding of the Place-world. Indiana University Press.

Casey, E. S. (2013). The Fate of Place: A Philosophical History. Univ of California Press.

Ceniza, C. (1982). Self Identity and the Filipino Philosophy. SOPHIA Trimestral Journal of the Department of Philosophy, De La Salle University, Manila, Philippines, 12 (1.), 17-25.

Craig, M., \& Casey, E. S. (2018). Thinking in Transit. In R. Scapp \& B. Seitz (Eds.), Philosophy, Travel, and Place: Being in Transit (pp. 51-67). Springer International Publishing. https://doi.org/10.1007/978-3319-98225-0_3

De Leon, E. C. (2016). An Interview with Romualdo Abulad, SVD. Kritike: An Online Journal of Philosophy, 101), 1-37. https://doi.org/10.25138/10.1.a.1

De Leon, E.C. (2017). Emerita S. Quito (1929 --): Ang Ugat ng Isang Panibagong Direksiyon ng Pamimilosopiya sa Pilipinas. MALAY29.2, 30-46.

Demeterio, F.P.A. (2014). Quito, Ceniza, Timbreza, Gripaldo: DLSU Professors' Contributions to Filipino

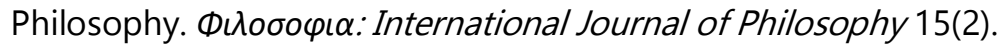

Fantini, G. (2011). Shattered Pictures of Places and Cities in George Santayana's Autobiography. Universitat de València.

Gianan, N. A. (2012). Philosophy and Dealienation of Culture: Instantiating the Filipino Experience. Cultura. International Journal of Philosophy of Culture and Axiology 9(2), 95-206.

Gripaldo, R. M. (1985). The North and South of a National Language $(1985,2014)$. Diliman Review. https://www.academia.edu/6128269/The_North_and_South_of_a_National_Language_1985_2014_

Gripaldo, R. M. (1988). Review of The State Of Philosophy In The Philippines. Monograph Series No. 5 [Review of Review of The State Of Philosophy In The Philippines. Monograph Series No. 5, by E. S. Quito]. Philippine Studies, 36(4), 520-522.

Gripaldo, R. M. (2004). My philosophical development. Filipino Philosophy: Traditional Approach.

Gripaldo, R. M. (2006) Is there a Filipino philosophy? The philosophical landscape: A panoramic perspective on philosophy. 3rd edition. Manila: Philippine National Philosophical Research Society. Available at https://www.academia.edu/4428503/Is_There_a_Filipino_Philosophy_2009_2013_

Gripaldo, R. M. (2009a). The making of a Filipino philosopher in The making of a Filipino philosopher and other essays. National Book Store.

Gripaldo, R. M. (2009b). Filipino philosophy and nation building in The making of a Filipino philosopher and other essays. National Book Store.

Gripaldo, R. M. (2014). Filipino Philosophy: Past and Present. National Conference of the Philosophical Association of the Philippines, Ateneo de Manila University, Quezon City.

Hardy, Stephen. (2000). Placiality: The Renewal Of The Significance Of Place In Modern Cultural Theory. 
Brno Studies In English 26, 85-100.

hooks, bell. (2009). Belonging: A Culture of Place. Routledge.

Joaquin, J. J. B. (2010). Gripaldo and Mabaquiao on Filipino Philosophy: A Critical Assessment of Two Attempts to Establish a Filipino Philosophy. DALUMATE-Journal, 1(1), 1-1.

Keyserling, H. G. von. (1925). The Travel Diary of a Philosopher. Harcourt, Brace.

Krell, D. F. (2018). Nietzsche vagabundus or, the Good European in transitu. In R. Scapp \& B. Seitz (Eds.), Philosophy, Travel, and Place: Being in Transit (pp. 169-188). Springer International Publishing. https://doi.org/10.1007/978-3-319-98225-0_11

Mabaquiao, N. M. (2012). Isang Paglilinaw sa Kahulugan at Kairalan ng Pilosopiyang Filipino= A Clarification in the Existence and Meaning of Filipino Philosophy. Malay, 24(2).

Malpas, J. (2018). Place and experience: A philosophical topography. Routledge.

Mercado, L. N. (1976). Elements of Filipino philosophy. Divine Word Univ.

Mercado, L. N. (1994). The Filipino Mind. CRVP.

Morgan, A. D. (2010). Journeys into transformation: Travel to an "other" place as a vehicle for transformative learning. Journal of Transformative Education, 8(4), 246-268.

Peters, M. A. (2010). Wittgenstein as Exile: A Philosophical Topography, Policy Futures in Education, 8 (3 \& 4), 446-456.

Quito, E. (1983). The State of Philosophy in the Philippines (Issue 5). De La Salle University Press.

Raadik-Cottrell, J. (2010). Cultural memory and place identity: Creating place experience. Colorado State University.

Rawlinson, M. C. (2018). Long Distances: Tourating, Travel, and the Ethics of Tourism. In R. Scapp \& B. Seitz (Eds.), Philosophy, Travel, and Place: Being in Transit (pp. 7-50). Springer International Publishing. https://doi.org/10.1007/978-3-319-98225-0_2

Santayana, G. (1964). The Philosophy of Travel. The Virginia Quarterly Review, 40(1), 1-10.

Scapp, R., \& Seitz, B. (2018). Philosophy, Travel, and Place: Being in Transit. Springer.

Thomas, E. (2020). The Meaning of Travel: Philosophers Abroad. Oxford University Press.

Timbreza, F. T. (1999). Intelektwalisasyon ng pilosopiyang Filipino. De la Salle University Press.

Timbreza, F. T. (2017). Artikulasyon ng Katutubong Pilosopiya. Malay, 30(1).

Wen-Hong, H. (2009). Frontiers of Japanese Philosophy 4: Facing the 21st Century. Nanzan Institute for Religion \& Culture.

Wollstonecraft, M. (1894). Letters Written During a Short Residence in Sweden, Norway, and Denmark. Cassell.

Hazel T. Biana is an Associate Professor at the Department of Philosophy of De La Salle University, Manila, Philippines, and a Research Fellow at the Southeast Asia Research Center and Hub (DLSU$\mathrm{SEARCH}$ ). She is also the Vice President of the Philosophical Association of the Philippines. While she specializes in topics on cultural criticism and intersectionality, she is also working on developing her theories on the philosophy of place and travel. 